\title{
Spectroscopic and chromatographic exploration of different phytochemical and mineral contents from Syzygium alternifolim (Wt.) Walp. an endemic, endangered medicinal tree taxon
}

\author{
Pulicherla Yugandhar*, Nataru Savithramma \\ Department of Botany, Sri Venkateswara University, Tirupati, India.
}

\begin{tabular}{|c|c|}
\hline ARTICLE INFO & ABSTRACT \\
\hline Article history: & \multirow{10}{*}{$\begin{array}{l}\text { The present study is aimed to explore different phytochemical and mineral contents in endemic medicinal plant- } \\
\text { Syzygium alternifolium. Different spectroscopic (UV-Vis, FT-IR, ICP-OES) and chromatographic techniques } \\
\text { (GC-MS) are used to identify versatile phytochemical and mineral contents in different parts of } S \text {. alternifolium } \\
\text { by qualitative and quantitative means. For qualitative phytochemical screening a total of } 16 \text { types of different } \\
\text { primary and secondary metabolites are extracted in } 07 \text { different solvents, among them } 15 \text { types of metabolites } \\
\text { out of } 16 \text { are identified in methanol extract. In quantitative analysis higher quantities of sugar i.e., } 45.2 \mathrm{mg} / \mathrm{g} \\
\text { among primary metabolites of fruit and } 451.20 \mathrm{mg} / \mathrm{g} \text { of phenols among secondary metabolites from stem bark } \\
\text { are quantified. FT-IR and GC-MS analysis of methanol extracts of plant reveals different functional groups and } \\
\text { phytochemical compounds. In addition to these, mineral analysis through ICP-OES shows higher quantities of } \\
\text { Potassium }(43.60 \mathrm{mg} / \mathrm{L}) \text { in fruit, Iron }(2.186 \mathrm{mg} / \mathrm{L}) \text { in stem bark among macro and micro elements respectively. } \\
\text { The results of the present study reveal, S. alternifolium is potential source towards number of phytochemicals } \\
\text { and different types of mineral contents. Hence, it becomes a treasure house for pharmaceutical as well as } \\
\text { nutraceutical companies to prepare novel products. }\end{array}$} \\
\hline Received on: $23 / 07 / 2016$ & \\
\hline Revised on: 11/08/2016 & \\
\hline Accepted on: & \\
\hline Available online: $31 / 01 / 2017$ & \\
\hline Key words: & \\
\hline Syzygium alternifolium, & \\
\hline phytochemical screening, & \\
\hline phytochemical compounds, & \\
\hline mineral contents. & \\
\hline
\end{tabular}

\section{INTRODUCTION}

Since ancient times, usage of medicinal plants all over the world due its preservative and medicinal values as well as to convey flavour to food and medicines preparation. In recent past, there has been growing interest in crude extracts of medicinal plants to develop food additives and different medicine formulations (Omran and Esmailzadeh, 2009). Medicinal plants, in all aspects of life served as valuable starting material for development of herbal drugs, which are rich source of phytochemical compounds (Sasidharan et al., 2011) and minerals (Ghani et al., 2014) build up them through by different primary and secondary metabolic processes. Identification of plant phytochemicals through phytochemical screening is considered

* Corresponding Author

Pulicherla Yugandhar, Department of Botany, Sri Venkateswara

University, Tirupati.E-mail id:yugandharbotany@gmail.com to be an effective discovering method for phytochemical constituents of medicinal plants responsible for important physiological functions in living beings (Yamashita et al., 2005). In addition to these, mineral nutrients are also needed for humans to maintain their health and proper organ function (Ballesta et al., 2010).

According to World Health Organization most of the human population relies chiefly on medicinal plants for their daily ailments. In India, most of the people also depend on traditional herbal medicine systems and still explored number of medicinal plants for their therapeutic activities. Due to this, India is a dictum of botanical garden to the world and a goldmine of well recorded and traditionally well practiced knowledge of herbal medicine (Savithramma et al., 2012). Various medicinal plants are also used as food along with their medicinal benefits, evaluating their mineral nutritional significance can help to understand the worth of medicinal plant species (Pandey et al., 2006). 
For this, analyses of different phytoconstituents and mineral nutrients of medicinal plants was carried out by efficient scholars through utilization of several advanced analytical tools like- quantification and identification of specific functional groups of compounds solely by their absorption characteristics through UV-Vis and FT-IR spectroscopy respectively (Baeten and Aparicio, 2000). Identification of specific unique phytochemical compounds by combination of Gas chromatography (GC) data coupled with mass spectra (MS) (Hemalatha et al., 2016) and quantification of different mineral elements by Inductively Coupled Plasma-Optical Emission Spectrometry (ICP-OES) (Senila et al., 2014). Now-a-days usage of these spectroscopic and chromatographic techniques in biology brought about for revolution in drug development, which explored more number of compounds and minerals present in medicinal plant parts, especially used in the preparation of herbal remedies to cure various diseases. Exploiting these techniques to identify the adulteration of drugs has become easy in the present scenario.

Phytochemicals are naturally occurring constituents in medicinal plants, which utilizes for defence mechanism to protect themselves, this specificity was precisely utilized to cure human diseases. These phytochemicals are mainly two groups, i.e., primary and secondary metabolites. Fatty acids, common sugars, proteins are included under primary metabolites; terpenoids, alkaloids, phenolic compounds, etc., are categorized under secondary metabolites. In recent past, analysis of phytochemicals by using UV-Vis spectroscopy, FT-IR and GC-MS techniques become firmly established as a key technological metabolic profiling of medicinal plants (Hemalatha et al., 2016). UV-Vis and FT-IR spectroscopic tools have the capacity to quantify and analyze functional groups of phytochemicals, GC-MS has proven to be a powerful tool and had separation efficiency suitable for separation of phytochemicals (Kopka, 2006). The human body requires a number of minerals in order to maintain good health which influences the biochemical processes of metabolism. A number of minerals essential to human nutrition accumulate in different parts of plants as it accumulates minerals essential for growth conveying from the environment (Ajasa et al., 2004). Study of the elements with respect to indigenous medicinal plant reveals that major and trace elements have significant roles in combating a variety of human ailments and diseases (Shirin et al., 2010). ICP-OES is an analytical tool to identify and quantify number of mineral contents from medicinal plants. For this ascertainment of phytochemicals and mineral elements present in plants is imperative, because of the concentration and type of mineral presence is most often be stipulated on the label of a medicine for effective usage of drugs. The important components like quality, type and concentration of a mineral play pivotal role in the preparation of medicine and curing of different degenerative diseases. In a recent past many of the researchers quantify different mineral contents from medicinal plants with the help of ICP-OES technique (Senila et al., 2014).

Syzygium alternifolium belongs to the family Myrtaceae and is locally known as mogi or adavinerudu. It is a deciduous tree, grown in top hills of dry deciduous forest in Sri Venkateswara Wildlife Sanctuary of Chittoor and Cuddapah Districts of Eastern Ghats, Andhra Pradesh, India. Most of the researches and Andhra Pradesh State Biodiversity Board has categorized this plant as endemic, and globally endangered species as per the criteria of International Union for Conservation of Nature-Conservation Assessment and Management Plan (IUCNCAMP) to these areas. Recently "The IUCN Red List of Threatened Species" categorized this plant under endangered state (Saha et al., 2015).

Traditionally the plant parts like tender shoots, leaves, fruits were used for the treatment of dysentery, joint pains, burning sensations in the stomach (Savitramma and Sulochana, 1997), diarrhoea (Savithramma et al., 2014a) and diabetes (Savithramma et al., 2014b) by local and tribal people of Tirumala hills. Researchers proved that different parts of the plant having antimicrobial (Yugandhar et al., 2015) and anticancer activity (Komuraiah et al., 2014). Previously preliminary phytochemical screening and isolation of triterpenoids from stem bark was done by Reddy et al., (2012), the flavonoid Eucalyptin 1 and a triterpinoid Epibetulinic acid 2 was done only by Komuraiah et al., (2014) from leaf part of the plant. But there is no proper report on quantification of phytochemicals and mineral content validation in different parts of S. alternifolium so far.

Hence the present study is undertaken to explore different primary and secondary metabolites through qualitative phytochemical screening by using different solvents, quantification of these metabolites by UV-Vis spectroscopy, validation of functional groups by FT-IR, identification of different bioactive compounds by GC-MS by using crude methanol extracts and quantification of essential mineral nutrients by ICP-OES technique.

\section{MATERIALS AND METHODS}

\section{Collection of plant material and Sample preparation}

The healthy, fresh parts like stem bark, leaves and ripen fruits were collected from Nagatheertham area of Tirumala hills, parts of Eastern Ghats situated in Chittoor District of Andhra Pradesh, India, during the period between June to August of 2015, under the age of 08 to 09 older plants grown at black loamy soils situated at higher altitudes.

The plant was authenticated and cross checked by herbarium deposited (voucher no. 121) in Department of Botany, Sri Venkateswara University, Tirupati. The freshly collected plant parts were washed 2 to 3 times in running tap water and shade dried up to 10-15 days at room temperature.

A $50 \mathrm{~g}$ of finely grounded powders was extracted with $250 \mathrm{ml}$ of different solvents like distilled water, benzene, chloroform, ethanol, hexane, methanol and petroleum ether by using soxhlet apparatus. These extracts are filtered through Whatman no. 1 filter paper and concentrated with the help of a rotary evaporator. The obtained residues were stored at $4^{0} \mathrm{C}$ for further screening of phytochemicals. 


\section{Qualitative phytochemical analysis}

$1 \mathrm{~g}$ of residues obtained above were re-suspended in 100 $\mathrm{ml}$ of their respective mother solutions. These solutions were used for preliminary phytochemical screening of different primary and secondary metabolites with the help of standard protocols (Harborne, 1998).

\section{Quantitative phytochemical analysis}

With the help of UV-Vis spectroscopy the quantitative analysis of different primary and secondary metabolites through standard protocols like proteins (Lowry et al., 1951), starch (McCready et al., 1950), sugar (DuBoise, 1956), lipids (Jayaraman, 1981), alkaloids (Trease and Evans, 2002), flavonoids (Chang et al., 2002), tannins and phenols (Makkar et al., 1993).

\section{FT-IR analysis}

Fourier-Transform Infra Red (FT-IR) spectra of methanol extracts were analyzed in the range of 4,000 to $500 \mathrm{~cm}^{-1}$ with an ALPHA interferometer (ECO-ATR), Bruker, Ettlingen, Karlsruhe, Germany by $\mathrm{KBr}$ pellet method.

\section{GC-MS analysis}

GC-MS analysis of crude methanol extracts were carried out on GC-MS QP2010 Shimadzu (Japan) system comprising a gas chromatograph interfaced to a mass spectrometer (GC-MS) instrument. The details of column used, carrier gas and maintenance of column temperature are followed by the method of Kumar et al., (2012).

\section{ICP-OES analysis}

The Perkin Elmer 7000DV ICP-OES (Shelton, CT, USA) model was used for determination of $\mathrm{Ca}, \mathrm{K}, \mathrm{Mg}, \mathrm{P}, \mathrm{B}, \mathrm{Cu}, \mathrm{Fe}, \mathrm{Mn}$, Mo and $\mathrm{Zn}$ in digested S. alternifolium samples. For this $100 \mathrm{mg}$ of dried plant powders were weighed in quartz vessels and digested with $1 \mathrm{ml}$ of $30 \% \mathrm{H}_{2} \mathrm{O}_{2}$ and $7 \mathrm{ml}$ of $70 \% \mathrm{HNO}_{3}$. The temperature was raised up to $170{ }^{\circ} \mathrm{C}$ for $10 \mathrm{~min}$. in a muffle furnace for effective digestion of samples. The obtained solutions were filtered and made up to $25 \mathrm{ml}$ with Milli-Q water.
Blank solutions were prepared for slot and the experiment was performed in triplicates (Babu and Savithramma, 2014).

\section{RESULTS}

\section{Qualitative phytochemical analysis}

In our studies the qualitative phytochemical screening of different parts of $S$. alternifolium reveals the presence of fatty acids, proteins, reducing sugars among primary metabolites. Alkaloids, anthocyanins, anthraquinones, coumarins, emodins, flavonoids, glycosides, leucoanthocyanins, lignins, phenols, saponins, tannins, triterpenoids among the secondary metabolites extracted with different solvents (Table 1). The highest number of phytochemicals were found in methanol extracts from all parts of the plant followed by distilled water and ethanol extracts. Distilled water and ethanol extracts yielded somehow same number of metabolites in different parts of the plant followed by benzene, chloroform, hexane and finally by petroleum ether. The metabolites like flavonoids and phenols obtained more repeatedly from the solvents like distilled water, benzene, chloroform, ethanol, hexane and methanol. Fatty acids, anthraquinones, coumarins and lignins were obtained very drastic in the extracts like, distilled water, benzene, chloroform, ethanol, methanol and petroleum ether.

\section{Quantitative phytochemical analysis}

According to qualitative phytochemical analysis (Table 1) more presence of phytochemicals in methanol/distilled water/ethanol extracts indicates ' ++ ' were selected for quantification studies. Reducing sugars (starch and sugar), fatty acids (lipids), proteins among primary metabolites; alkaloids, flavonoids, tannins, phenols among secondary metabolites were subjected to quantification with the help of UV-Vis spectroscopy. When compare to all the studied plant parts, higher quantity of primary metabolite like sugar was present in fruit part of the plant followed by starch, proteins and lipids in leaf part of the plant. Among the secondary metabolites, higher quantity of phenols were quantified in stem bark followed by flavonoids in leaf part, alkaloids and tannins in stem bark of the plant (Table 2).

Table 1: Qualitative phytochemical analysis of different primary and secondary metabolites from different parts of S. alternifolium.

\begin{tabular}{|c|c|c|c|c|c|c|c|c|c|c|c|c|c|c|c|c|c|c|c|c|c|c|}
\hline \multirow[t]{2}{*}{ S. No } & \multirow{2}{*}{$\begin{array}{l}\text { Phytochemical } \\
\text { constituents }\end{array}$} & \multicolumn{3}{|c|}{ Benzene } & \multicolumn{3}{|c|}{ Chloroform } & \multicolumn{3}{|c|}{ Distilled water } & \multicolumn{3}{|c|}{ Ethanol } & \multicolumn{3}{|c|}{ Hexane } & \multicolumn{3}{|c|}{ Methanol } & \multicolumn{3}{|c|}{ Petroleum ether } \\
\hline & & $\mathbf{S}$ & $\mathbf{L}$ & $\mathbf{F}$ & $\mathbf{S}$ & $\mathbf{L}$ & $\mathbf{F}$ & $\mathbf{S}$ & $\mathbf{L}$ & $\mathbf{F}$ & $\mathbf{S}$ & $\mathbf{L}$ & $\mathbf{F}$ & $\mathbf{S}$ & $\mathbf{L}$ & $\mathbf{F}$ & $\mathbf{S}$ & $\mathbf{L}$ & $\mathbf{F}$ & $\mathbf{S}$ & $\mathbf{L}$ & $\mathbf{F}$ \\
\hline 1. & Fatty acids & - & - & - & - & - & - & - & - & - & - & + & + & - & - & - & + & + & + & - & + & + \\
\hline 2. & Proteins & - & - & + & - & + & - & ++ & ++ & ++ & ++ & + & + & + & - & - & ++ & ++ & ++ & - & - & - \\
\hline 3. & Reducing sugars & - & - & - & - & - & - & + & + & ++ & + & ++ & ++ & + & + & - & + & + & ++ & - & - & + \\
\hline 4. & Alkaloids & + & + & - & - & - & - & + & + & ++ & ++ & ++ & ++ & - & - & + & ++ & ++ & ++ & - & - & - \\
\hline 5. & Anthocyanins & - & - & + & - & - & - & ++ & ++ & + & ++ & + & + & - & - & - & ++ & ++ & + & - & - & - \\
\hline 6. & Anthraquinones & - & - & - & - & - & - & ++ & + & + & ++ & + & - & - & - & - & ++ & + & + & - & - & - \\
\hline 7. & Coumarins & + & + & + & - & - & - & + & + & - & - & - & - & - & - & - & - & - & + & + & - & - \\
\hline 8. & Emodins & - & - & - & - & - & - & + & + & + & ++ & + & + & - & - & - & + & + & + & - & - & - \\
\hline 9. & Flavonoids & + & + & + & - & - & - & ++ & ++ & ++ & ++ & ++ & + & + & + & - & ++ & ++ & + & + & + & - \\
\hline 10. & Glycosides & - & - & - & - & - & - & + & ++ & + & ++ & + & + & - & - & - & + & + & + & - & - & - \\
\hline 11. & Leucoanthocyanins & - & - & - & - & - & - & ++ & ++ & + & ++ & ++ & + & - & - & - & ++ & ++ & + & - & - & - \\
\hline 12. & Lignins & - & - & - & + & + & + & - & - & - & + & + & - & - & - & - & + & + & - & - & - & - \\
\hline 13. & Phenols & + & + & + & + & + & - & ++ & ++ & ++ & ++ & ++ & + & - & - & + & ++ & ++ & ++ & - & - & - \\
\hline 14. & Saponins & - & - & - & + & - & + & + & + & + & + & + & + & - & - & - & + & + & + & - & - & - \\
\hline 15. & Tannins & - & - & - & + & + & + & ++ & ++ & ++ & ++ & ++ & ++ & - & - & - & ++ & ++ & ++ & - & - & - \\
\hline 16. & Triterpenoids & - & - & - & - & - & - & + & + & + & - & - & + & - & - & - & + & + & + & - & - & - \\
\hline
\end{tabular}


Table 2: Quantitative estimation of different primary and secondary metabolites from different parts of S. alternifolium (mg/g Dwt.)

\begin{tabular}{ccccc}
\hline \multirow{2}{*}{ S. No } & Quantification of & \multicolumn{3}{c}{ Concentration $(\mathbf{m g} / \mathbf{g})$} \\
\cline { 2 - 5 } & Phytochemicals & Stem bark & Leaf & Fruit \\
\hline 1. & Proteins & $4.81 \pm 0.05$ & $5.72 \pm 0.07$ & $4.25 \pm 0.04$ \\
2. & Starch & $8.50 \pm 0.14$ & $14.33 \pm 0.24$ & $8.33 \pm 0.10$ \\
3. & Sugar & $12.4 \pm 0.07$ & $32.8 \pm 0.47$ & $45.2 \pm 0.26$ \\
4. & Lipids & $0.18 \pm 0.004$ & $0.24 \pm 0.010$ & $0.03 \pm 0.004$ \\
5. & Alkaloids & $0.32 \pm 0.007$ & $0.30 \pm 0.004$ & $0.153 \pm 0.001$ \\
6. & Flavonoids & $35.4 \pm 0.36$ & $99.8 \pm 0.54$ & $31.5 \pm 0.26$ \\
7. & Tannins & $0.16 \pm 0.005$ & $0.10 \pm 0.002$ & $0.06 \pm 0.0003$ \\
8. & Phenols & $451.20 \pm 0.84$ & $374.40 \pm 0.50$ & $325.03 \pm 1.84$ \\
\hline
\end{tabular}

Values are average of triplicates, \pm indicates standard error

Table 3: FTIR analyses of functional groups from different parts of S. alternifolium.

\begin{tabular}{|c|c|c|c|c|}
\hline \multirow{2}{*}{ S. No } & \multicolumn{3}{|c|}{ Peak assignment $\left(\mathrm{cm}^{-1}\right)$} & \multirow{2}{*}{ Corresponding functional group } \\
\hline & Stem bark & Leaf & Fruit & \\
\hline 1. & 3338 & 3332 & 3338 & $\mathrm{O}-\mathrm{H}$ bond of alcohols or phenols \\
\hline 2. & 2945 & 2928 & 2935 & $\mathrm{C}-\mathrm{H}$ stretch of alkanes \\
\hline 3. & 2835 & 2842 & 2839 & $\mathrm{C}-\mathrm{H}$ stretch of aldehydes \\
\hline 4. & & 1689 & & $\mathrm{C}=\mathrm{O}$ stretch of carboxylic acids \\
\hline 5. & 1645 & 1615 & 1648 & $\mathrm{~N}-\mathrm{H}$ bend of $1^{\circ}$ amines \\
\hline 6. & 1449 & 1450 & 1447 & $\mathrm{C}-\mathrm{H}$ bend of alkanes \\
\hline 7. & & 1377 & & $\mathrm{C}-\mathrm{H}$ bend of alkenes \\
\hline 8. & 1223 & 1217 & & $\mathrm{C}-\mathrm{N}$ stretch of aliphatic amines \\
\hline 9. & 1109 & 1103 & & $\mathrm{C}-\mathrm{N}$ stretch of aliphatic amines \\
\hline 10. & 1017 & 1018 & 1016 & C-O stretch of alcohols, carboxylic acids, esters, ethers \\
\hline 11. & 656 & 657 & 699 & $\mathrm{C}-\mathrm{Br}$ stretch of alkyl halides \\
\hline
\end{tabular}

\section{FT-IR analysis}

Qualitative phytochemical screening reveals that the methanol extract solubilises more number of metabolites when compare to other studied solvents. Due to this we use these crude methanol extracts for FT-IR and GC-MS studies. With the help of FT-IR, methanol extracts of different parts were used to identify functional groups of different phytochemicals in the range of 4,000 to $500 \mathrm{~cm}^{-1}$ of the mid IR region [Figure 1; Table 3]. The FT-IR spectrum of methanol extracts of stem bark, leaf and fruit gives a number of absorption peaks and their corresponding functional groups like alcohols, aldehydes, aliphatic amines, alkanes, alkyl halides, amines, carboxylic acids, esters, ethers and phenols.

\section{GC-MS analysis}

Gas chromatography analyses in combination with mass spectra of methanol extracts were analyzed to know the different phytochemical compounds along with their molecular weight and molecular formula. The unknown spectrum gets from the plant [Figure 2] extracts were compared with the spectrum of known compounds stored in National Institute of Standard and Technology (NIST) library.

Nature of the chemical compound, retention time, area $\%$, molecular weight, molecular formula, name and from which part of the plant they were separated was enumerated in Table 4. Nearly 40 types of different compounds were identified in all the studied plant parts, among them Octamethylcyclotetrasiloxane $\left(\mathrm{C}_{8} \mathrm{H}_{24} \mathrm{O}_{4} \mathrm{Si}_{4}\right) \quad$ with $31.75 \%$, Hexamethylcyclotrisiloxane $\left(\mathrm{C}_{6} \mathrm{H}_{18} \mathrm{O}_{3} \mathrm{Si}_{3}\right)$ with $26.24 \%$ in stem bark, Diethoxydimethylsilane $\left(\mathrm{C}_{6} \mathrm{H}_{16} \mathrm{O}_{2} \mathrm{Si}\right)$ with $45.26 \%$, Acetaldehyde $\left(\mathrm{C}_{6} \mathrm{H}_{14} \mathrm{O}_{2}\right)$ with $5.67 \%$ in leaves, Diethoxydimethylsilane $\left(\mathrm{C}_{6} \mathrm{H}_{16} \mathrm{O}_{2} \mathrm{Si}\right)$ with $26.04 \%$ and Zapotin $\left(\mathrm{C}_{19} \mathrm{H}_{18} \mathrm{O}_{6}\right)$ with $13.78 \%$ in fruit part of the plant shows highest peak areas represents as principal components and compounds like 1,5-Diphenyl-2H-1,2,4-triazoline-3-thione; iethoxydimethylsilane; Ethylidene diethyl ether; Furfural; Methylsilane; Phosphine oxide, bis(pentamethylphenyl) were repeated compounds in the studied plant parts.

\section{ICP-OES analysis}

The ICP-OES analysis of different parts of the plant shows highest concentration of potassium $(43.60 \mathrm{mg} / \mathrm{L})$ in upper part of the plant like fruits among macro elements and iron (2.186 $\mathrm{mg} / \mathrm{L}$ ) in lower part of the plant like stem bark among micro elements (Table 5).

When compared to all the parts of $S$. alternifolium, fruit part of the plant having higher number of elements with higher concentrations like potassium $(43.60 \mathrm{mg} / \mathrm{L})$, magnesium $(10.03$ $\mathrm{mg} / \mathrm{L})$, phosphorus $(5.793 \mathrm{mg} / \mathrm{L})$, copper $(0.051 \mathrm{mg} / \mathrm{L})$ and zinc $(0.197 \mathrm{mg} / \mathrm{L})$. This fruit part was followed by stem bark, having calcium $(38.37 \mathrm{mg} / \mathrm{L})$, iron $(2.186 \mathrm{mg} / \mathrm{L})$ molybdenum $(0.131$ $\mathrm{mg} / \mathrm{L})$ and leaf part having boron $(0.458 \mathrm{mg} / \mathrm{L})$ and manganese $(0.584 \mathrm{mg} / \mathrm{L})$ at higher concentrations. 


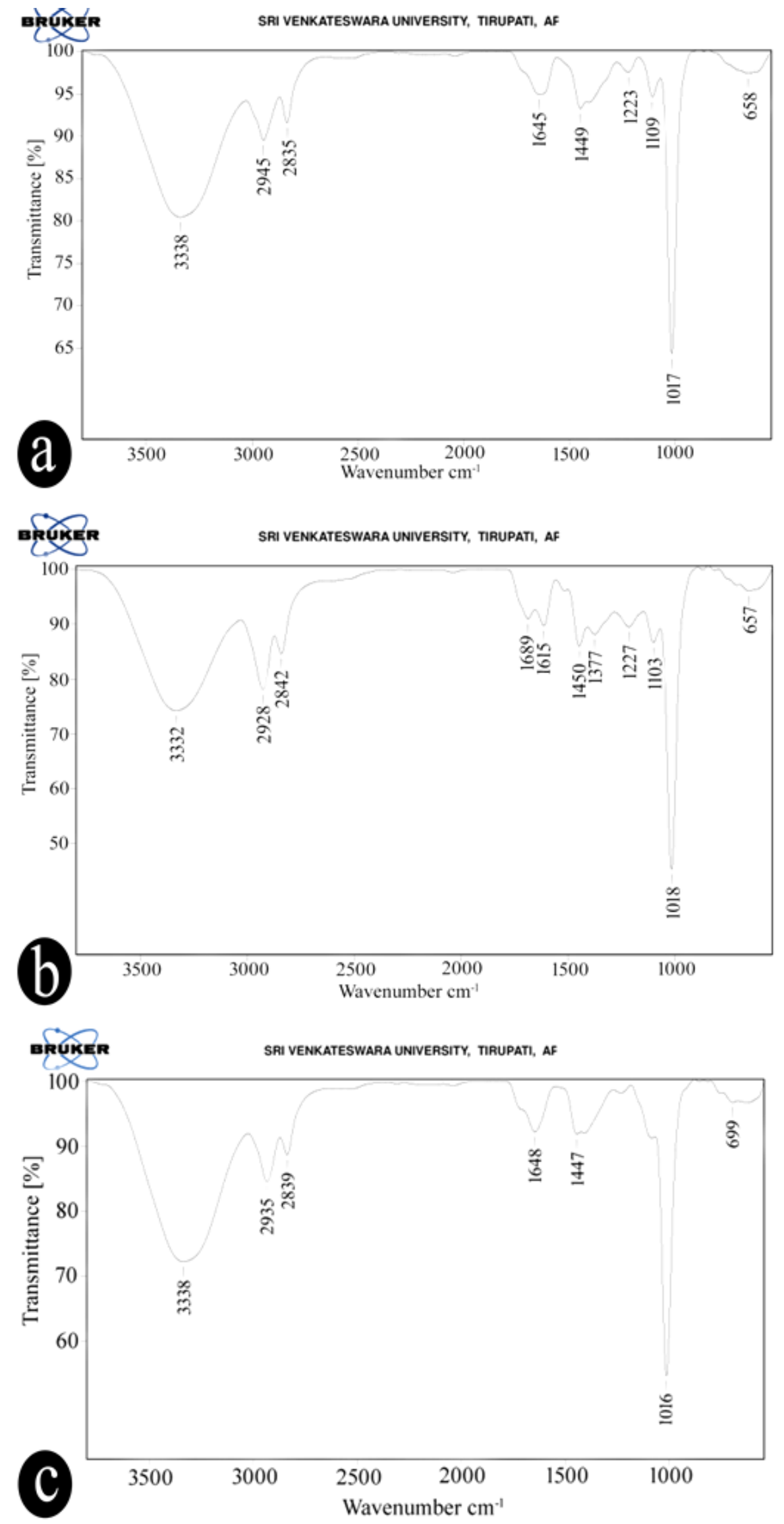

Fig. 1: FTIR spectral analyses for methanol extracts of S. alternifolium a: Stem bark extract b: Leaf extract c: Fruit extract. 

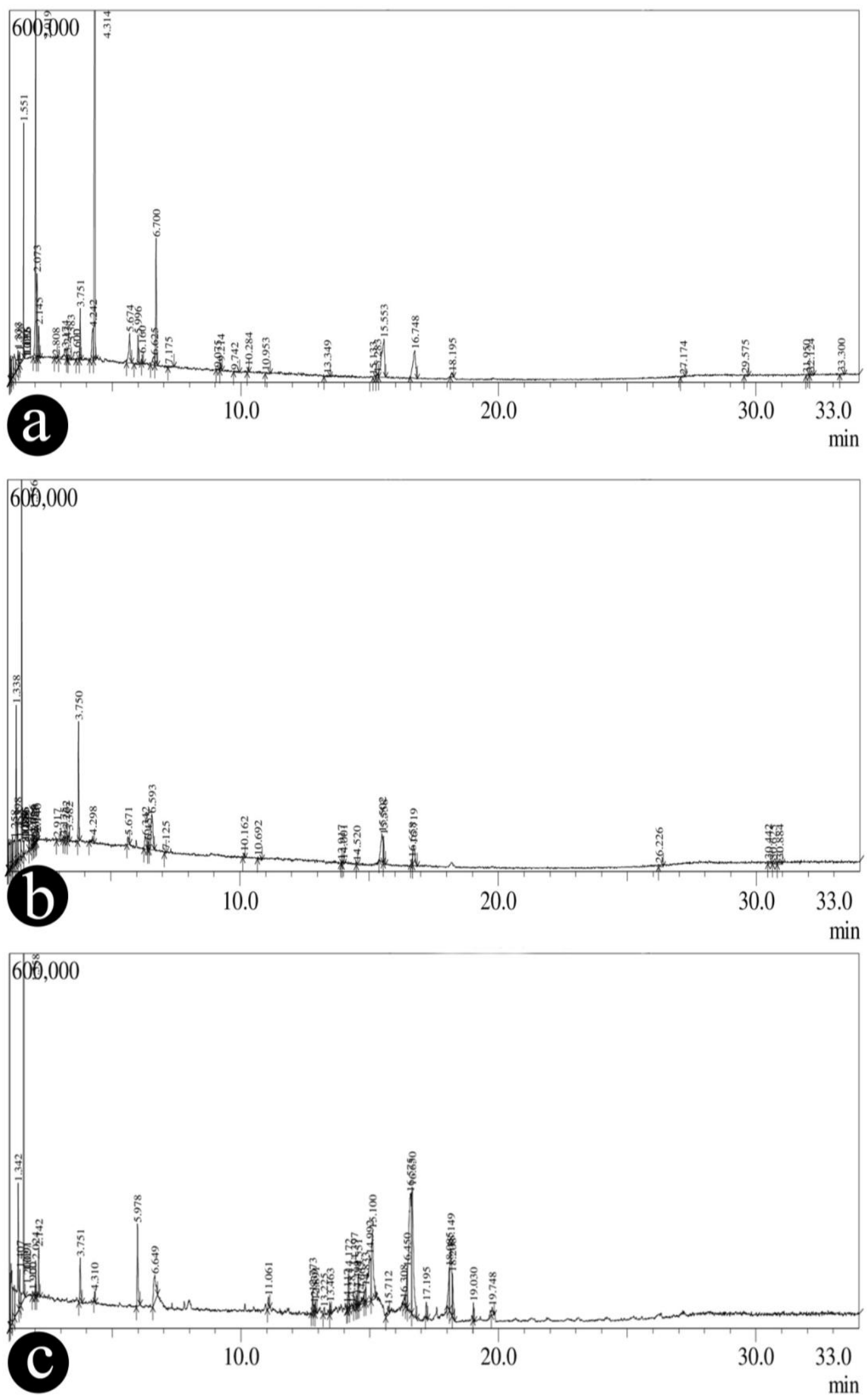

Fig. 2: GC-MS chromatographs of methanol extracts of S. alternifolium a: Stem bark extract b: Leaf extract c: Fruit extract. 


\section{Stembark}

Ca 317.9
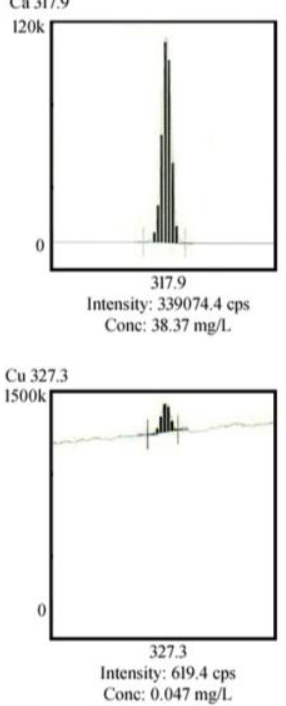

Leaf

Ca 317.9

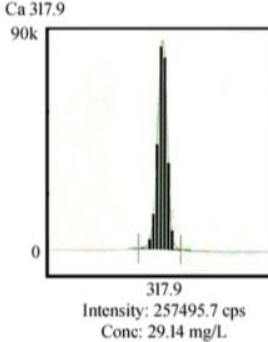

Conc: $29.14 \mathrm{mg} / \mathrm{L}$

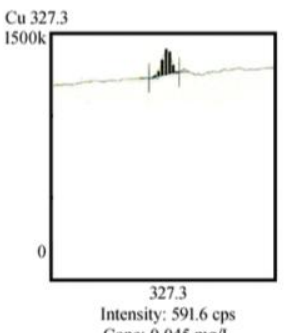

Fruit
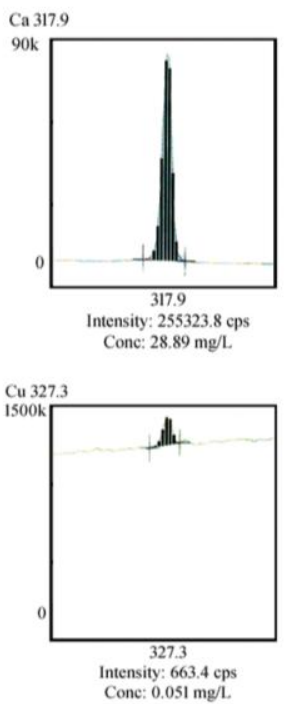
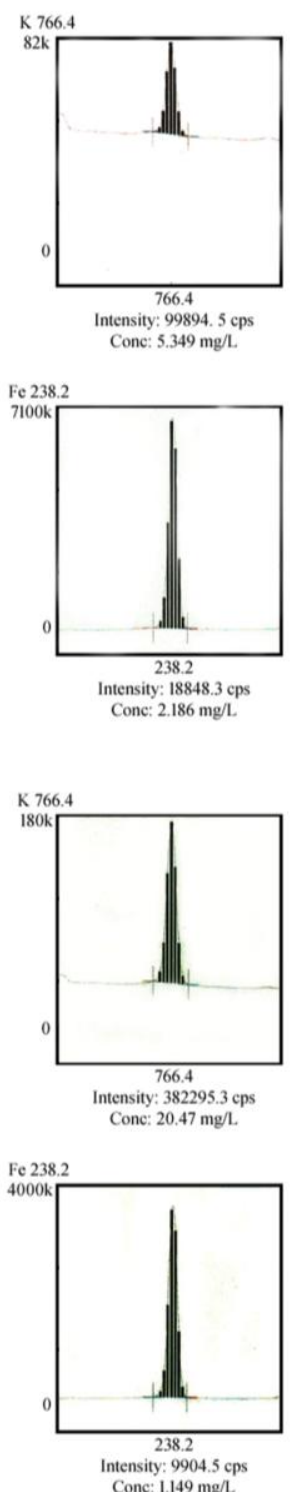

Conc: $1.149 \mathrm{mg} / \mathrm{L}$
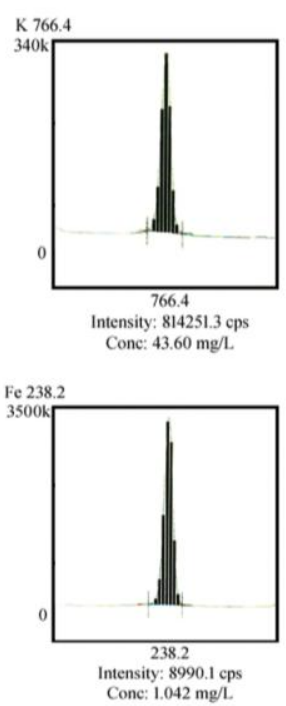
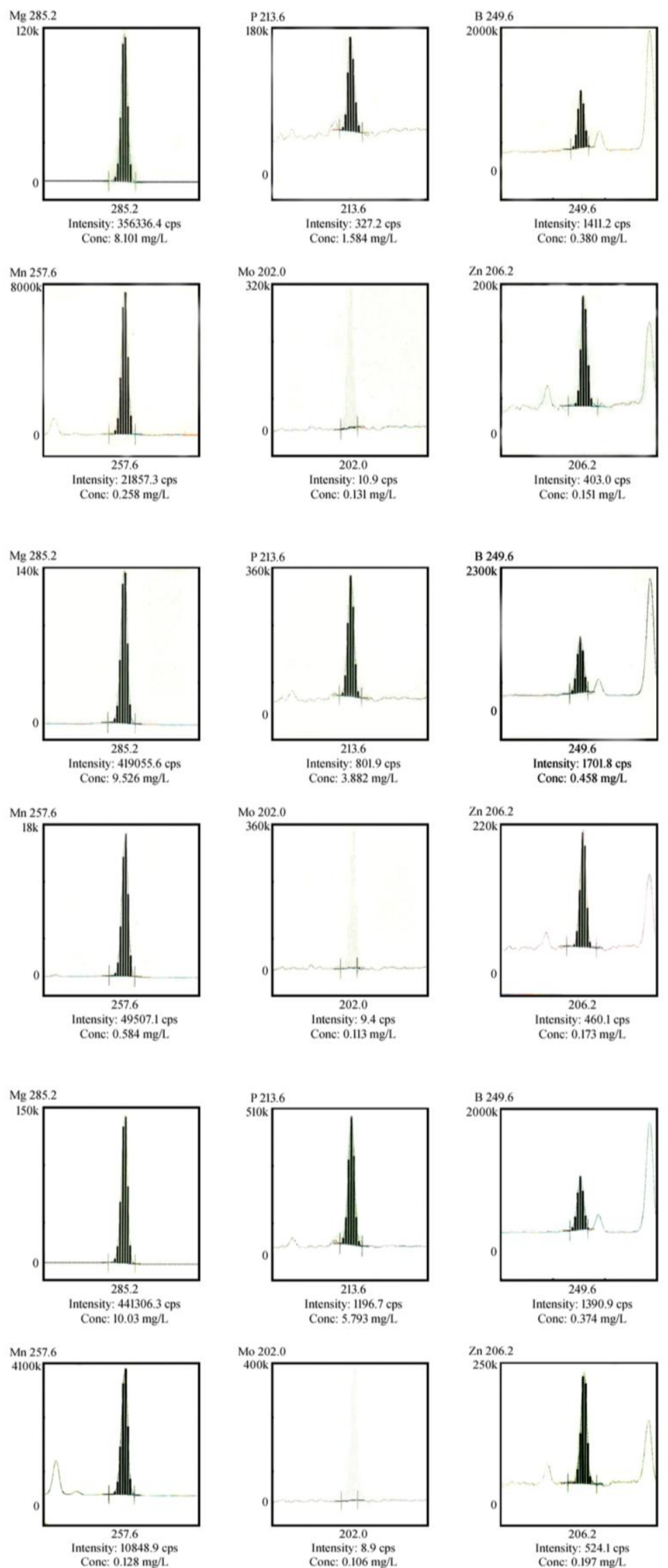
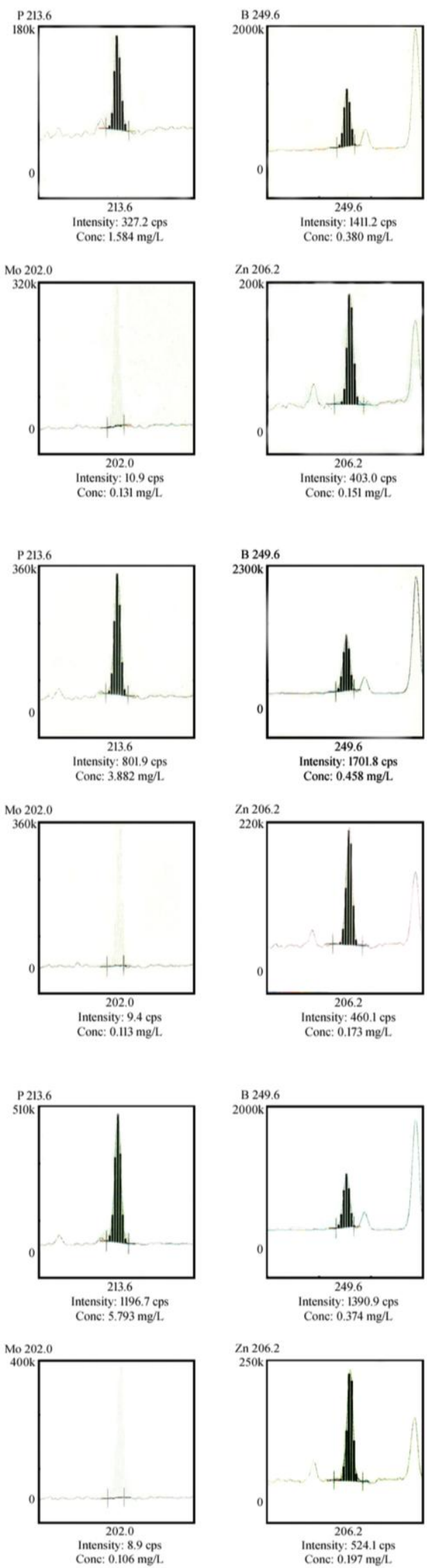

Fig. 3: ICP-OES spectral analyses for mineral constituents in different parts of S. alternifolium. 
Table 4: GC-MS analyses for methanol extracts of different parts of s. alternifolium.

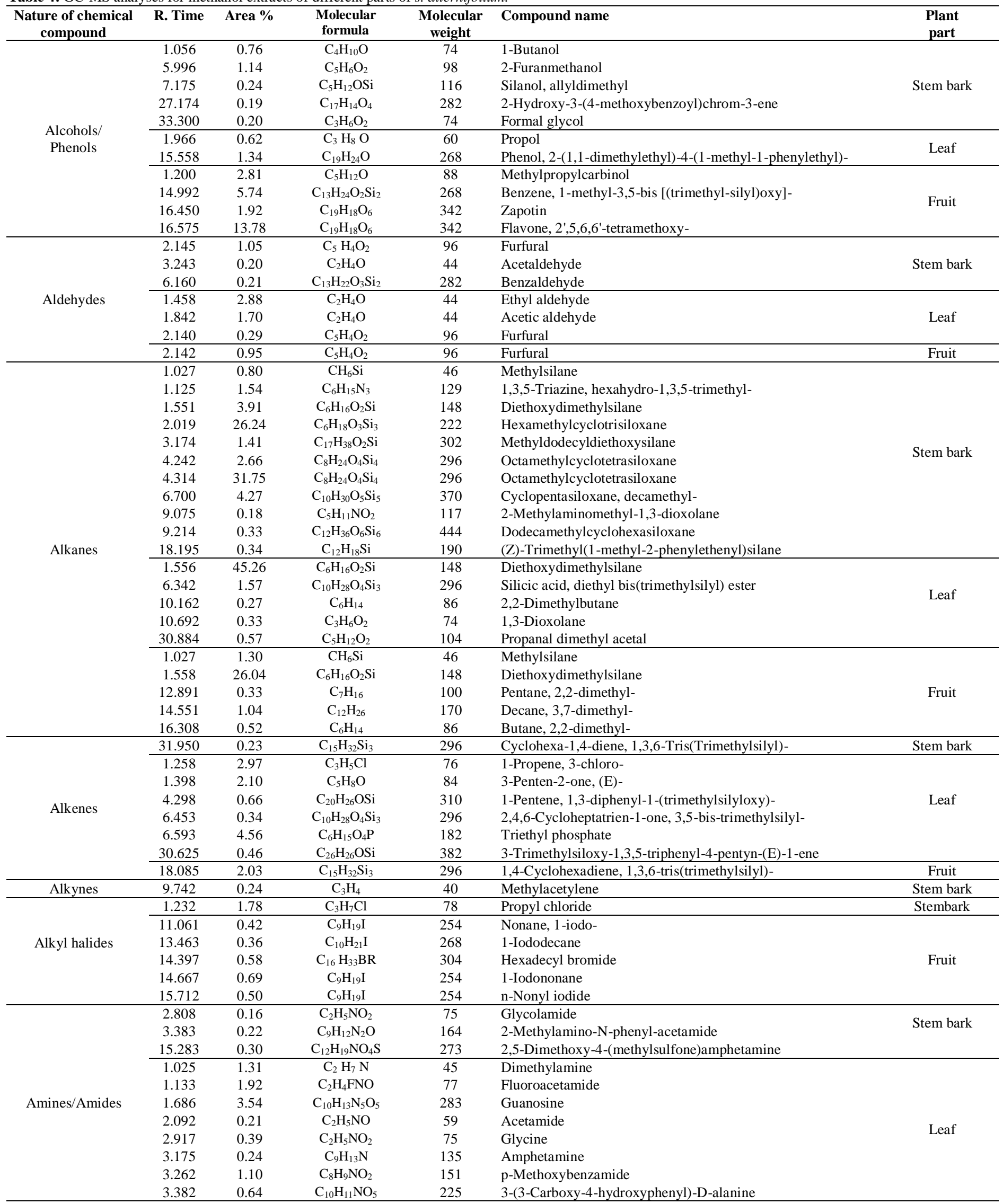




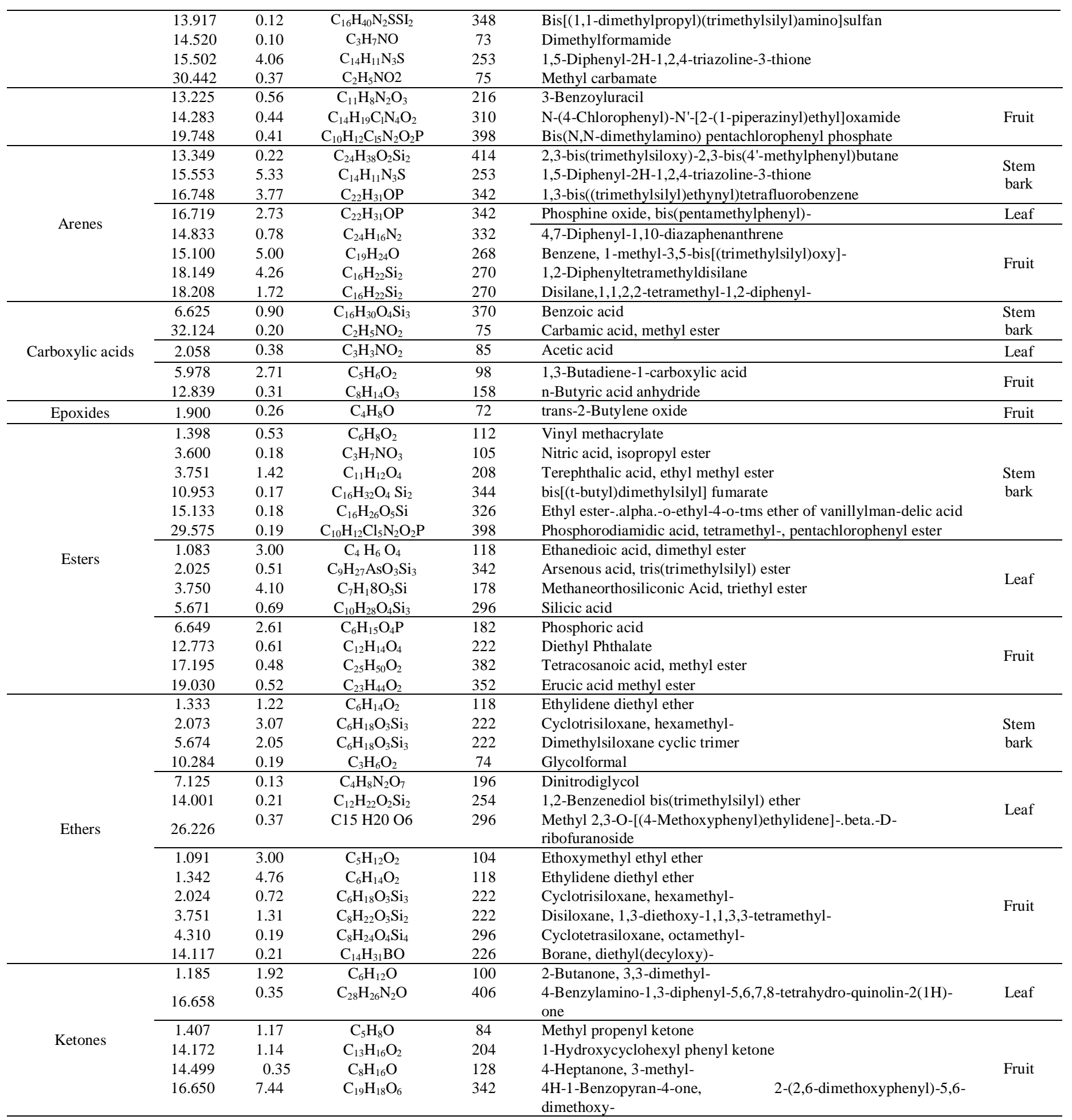


Table 5: Structure and medicinal uses of compounds separated with GC-MS.

\begin{tabular}{ccc}
\hline Name of the compound & Structure of the compound & Dr. Dukes medicinal use \\
\hline Furfural & Antiseptic, Flavor, Fungicide, Insecticide, Irritant, Pesticide.
\end{tabular}

Acetaldehyde

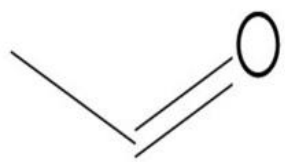

Addictive, Fungicide, Perfumery, Pesticide, Respiraparalytic, Tyrosinase-Inhibitor

\begin{tabular}{|c|c|}
\hline Benzaldehyde & $\begin{array}{l}\text { Allergenic, Anesthetic, Antibacterial, Anticancer, Antimutagenic, Antiseptic, Antispasmodic, } \\
\text { Antitumor, Candidicide, Flavor, Immunostimulant, Insecticide, Insectifuge, Motor- } \\
\text { Depressant, Nematicide, Pesticide, Sedative, Termiticide, Tyrosinase-Inhibitor. }\end{array}$ \\
\hline Benzoic acid & $\begin{array}{l}\text { Allergenic, Anesthetic, Antibacterial, Antiotitic, Antipyretic, Antisalmonella, Antiseptic, } \\
\text { Antiyeast, Choleretic, Expectorant, Flavor, Fungicide, Insectifuge, Pesticide, Phytoalexin, } \\
\text { Tyrosinase-Inhibitor, Uricosuric, Vulnerary. }\end{array}$ \\
\hline \multicolumn{2}{|r|}{ Leaf } \\
\hline Dimethylamine & Coleoptophile, Pesticide. \\
\hline Glycine & $\begin{array}{l}\text { Antiacid, Antialdosteronic, Antidote (Hypoglycin-A), Antiencephalopathic, Antigastritic, } \\
\text { Antiprostatitic, Antipruritic, Antisickling, Antiulcer, Cancer-Preventive, Neuroinhibitor, } \\
\text { Uricosuric. }\end{array}$ \\
\hline Silicic acid & Antidiabetic \\
\hline Acetic acid & \multirow[t]{2}{*}{$\begin{array}{l}\text { Acidulant Antibacterial, Antiotitic, Antisalmonella, Antivaginitic, Expectorant, Fungicide, } \\
\text { Keratitigenic, Mucolytic, Osteolytic, Perfumery, Pesticide, Protisticide, Spermicide, } \\
\text { Ulcerogenic, Verrucolytic. }\end{array}$} \\
\hline & \\
\hline Phosphoric acid & Acidulant, Additive, Flavor, Sequestrant. \\
\hline
\end{tabular}




\section{DISCUSSION}

Phytochemical screening tests were used for detection of different phytochemical compounds and discovery of new drugs subsequently may lead to the way of treatment to different diseases (Soares et al., 2013). Among the qualitative phytochemical screening methanol extract reveals the higher number of phytochemicals, it may be due to the extracting ability and polarity difference of compounds found in plants (Hawaze et al., 2012). Same type of results was found in the genus $S$. cumini (Bigoniya et al., 2012), and S. cordatum (Sidney et al., 2015) resulted more number of phytochemicals in methanol extract. Whereas in the case of quantification studies higher quantity of phenols were resulted in all the parts of the plant, it may be due to the selected plant is an intelligent one to accumulate these phenols to get protection from different biotic stresses and from different herbivore animals. This type of higher accumulation of phenols was found in the genus $S$. cordatum (Ndhlala et al., 2008). Primary metabolites are compounds that have essential roles associated with photosynthesis, respiration, growth and development. Secondary metabolites are those compounds synthesized by plants have a key role in protecting themselves from herbivores and microbial infections which have different therapeutic activities useful for mankind like, alkaloids isolated from Sarcococca ruscifolia having cytotoxic activity (Zhang et al., 2015) and from Alstonia scholaris having antibacterial activity (Liu et al., 2015). Flavonoids from Cyclocarya paliurus having antioxidant activity (Xie et al., 2015) and Chrozophora tinctoria having antiinflammatory activity (Abdallah et al., 2015). Phenolic compounds possess a wide spectrum of biochemical activities such as antioxidant, antimutagenic, anticarcinogenic as well as ability to modify the gene expression (Nakamura et al., 2003; Tapiero et al., 2002). The tannin containing remedies is used as antioxidant, antimicrobial and anti-viral purposes (Buzzini et al., 2008; Koleckar et al., 2008).

FT-IR is an analytical tool to detect different functional groups of plant material, which was used as a supportive tool in between qualitative phytochemical screening and GC-MS studies to enumerate different phytochemicals emerged from GC-MS. The functional groups appeared in FT-IR was correlated to qualitative phytochemical screening of methanol extracts and these studies pave a way for effective separation of different phytochemical compounds with the help of GC-MS. GC-MS is a hyphenated sensitive tool to separate group of chemical compounds into a single compound based on their molecular weight. Among the compounds separated in GC-MS instrument, the major compounds like Octamethylcyclotetrasiloxane is an organocyclic silicon compound used in the preparation of industrial silicone polymers and personal care appliances, it exhibits mild estrogenic activity in mice (He et al., 2003). Hexamethylcyclotrisiloxane is a volatile methyl siloxane used for the preparation of liquid silicones and is an ingredient of lotions, fragrances and in skin care products (Wang et al., 2009). Octamethylcyclotetrasiloxane and Hexamethylcyclotrisiloxane are found as major compounds in $S$. alternifolium stem bark and which was also found in medicinal plants like Olea europaea (Mostafa et al., 2011) and Bauhinia acuminata (Krishna et al., 2015) respectively as major components. Acetaldehyde isolated from leaves is an important aldehyde group of organic compound occur widely in coffee, bread, fruits and produced by many of the medicinal plants, having different biological activities or properties like addictive, fungicide, perfumery, pesticide, respiraparalytic, tyrosinase inhibitor (Dukes, 2013). Diethoxydimethylsilane is a flavonoid compound found in leaf and fruit parts of studied plant, having silicon as a major component and it act as excellent antimicrobial agent on different bacterial and fungal pathogens (Sihag et al., 2014). This compound was also separated in leaf extracts of Vitis vinifera (Ceyhan et al., 2012). Zapotin a natural chemo-preventive agent isolated from studied fruit part of the plant and also from Casimiroa edulis fruit having anticancer activity against human promyelocytic leukaemia HL-60 cells (Maiti et al., 2007). Along with these, many of the compounds separated from plant parts having different biological activities when they were substituted in Dr. Duke's phytochemical and ethnobotanical database developed by Dr. Jim Duke of the Agricultural Research Service/USDA (Dukes, 2013) (Table 5).

The separated major compounds like Diethoxydimethylsilane, Acetaldehyde having antimicrobial activity and Zapotin having anticancer activity which were correlated to traditional uses of plant utilized by different ethnic groups with Dr. Duke's phytochemical and ethnobotanical database. Along with these, the minor compounds like Acetic acid, Benzaldehyde, Benzoic acid and Furfural having antimicrobial activity. Glycine acts as antiacid, antigastritic and having antiulcer activity, Benzaldehyde and Glycine having anticancer activity, finally the Silicic acid having antidiabetic activity.

The quantification of minerals with ICP-OES reveals potassium among macro and iron among micro elements as higher concentrations at upper part of the plant like fruits and lower part of the plant like stem bark respectively. The same type of results was found in Chrysanthemum indicum, reveals higher concentrations of potassium in upper part and iron in lower part of the plant (Cui et al., 2012). This may be due to, higher mobility of potassium among plant body through the xylem and deposited higher concentrations in fruits at the time of senescence or leaf falling stage. Whereas mobility of minerals like calcium, boron, iron and manganese are drastic and deposited at higher concentrations in lower parts of the plants like stem bark and leaves (Marschner et al., 1996). Among the quantification of 10 mineral elements, fruit part of the plant having higher number of elements. This type of results was noticed in Salvia sclarea fruit part (Szentmihalyi et al., 2009). Potassium is found especially high concentrations within plant cells, mixed diet and is highly concentrated in fruits (Bhaskarachary et al., 2011). The tribal people of Tirumala hills eaten as ripen fruits as raw edible fruit and make into squashes and jellies used as food stuff (The Wealth of India, 1976), which may facilitates the tribal haleness. Consumption of wild edible plants containing minerals are needed 
for different physiological functions of human body (Turan et al., 2003), which play an important role in formation of active chemical constituents in medicinal plants and increasing the therapeutic action of prepared medicine (Adebajo et al., 2013).

\section{CONCLUSION}

In the present study we prove that the $S$. alternifolium have characteristic phytochemical and mineral composition in different parts of the plant. Methanol solvent has best extractive ability to extract different primary and secondary metabolites from this plant, which pave a way for functional groups analysis by FTIR and separation studies by GC-MS analyses. Existence of higher quantities of sugars among primary and phenols among secondary metabolites may conclude that the plant parts was rich source for energy utilization and may act as a good source towards antioxidants. GC-MS analysis of plant parts reveals different types of phytochemicals have biological activities, which may helpful to pharmacists to prepare novel drug formulations. ICP-OES analysis of plant revealed the measurable quantities of different mineral nutrients, consumption of this plant parts in different forms may useful to regulate different metabolic regulations in human beings. From these studies we explore that the plant $S$. alternifoilum was not only important towards medicinally, but also for nutritionally and helpful to local people, who are utilized this plant as edible as well as for medicinal significances by more authentic way. Some members of local people endorse stem bark, leaf and fruits from the plant aggressively, due its high medicinal significance and somehow cut off the entire plant. Recent time's the plant fetches high index of forest fires, subjected to different types of diseases and faces many more threats from different ways. Finally we suggest this plant as a treasure house for pharma and neutraceutical companies to prepare novel drug and food formulations and utilize this plant parts as sustainable way not by in destructive way.

\section{ACKNOWLEDGEMENT}

We owe a special debt of gratitude to Dr. K. Suma Kiran, Department of English, Sri Venkateswara University for assisting language correction.

Financial support and sponsorship: The first author is highly grateful to UGC-BSR for providing meritorious fellowship and to Prof. K. Seshaiah, Dept. of Chemistry and DST-PURSE, Sri Venkateswara University, Tirupati for providing characterization facilities.

Conflict of Interests: There are no conflicts of interest.

\section{REFERENCES}

Abdallah HM, Almowallad FM, Esmat A, Shehataa IA, SattaraEAA. Anti-inflammatory activity of flavonoids from Chrozophora tinctoria. Phytochem Lett, 2015; 13:74-80.
Adebajo AC, Ayoola MD, Odediran SA, Aladesanmi AJ, Schmidt TJ, Verspohl EJ. Evaluation of ethnomedical claims III: antihyperglycaemic activities of Gongronema latifolium root and stem. J Diabetes, 2013; 5(3):336-343.

Ajasa A, Bello MO, Ibrahim AO, Ogunwande IA, Olawore NO. Heavy trace metals and macronutrients status in herbal plants of Nigeria. Food Chem, 2004; 85(1):67-71.

Babu RH, Savithramma N. Evaluation of grass species for elements through ICP-OES technique. Int J Pharm Sci Res, 2014; 5(11):4908-4915.

Baeten V, Aparicio R. Edible oils and fats authentication by fourier transformed raman spectrometry. Biotechnol Agron Soc Environ, 2000; 4(4):196-203.

Ballesta MCM, Perles RD, Moreno DA, Muries B, Lopez CA, Bastias E, Viguera CG, Carvajal M. Minerals in plant food: effect of agricultural practices and role in human health. a review. Agron Sustain Dev, 2010; 30(2):295-309.

Bhaskarachary K. Potassium and human nutrition: The soilplant-human continuum. Karnataka J Agric Sci, 2011; 24(1): 9-44.

Bigoniya P, Singh CS, Srivastava B. Pharmacognostical and physico-chemical standardization of Syzygium cumini and Azadirachta indica seed. Asian Pac J Trop Biomed, 2012:S290-S295.

Buzzini P, Arapitsas P, Goretti M, Branda E, Turchetti B, Pinelli P, Ieri F, Romani A. Antimicrobial and antiviral activity of hydrolysable tannins. Mini Rev Med Chem, 2008; 8(12):1179-1187.

Ceyhan N, Keskin D, Zorlu Z, Ugur A. In-vitro antimicrobial activities of different extracts of grapevine leaves (Vitis vinifera $\mathrm{L}$.) from west anatolia against some pathogenic microorganisms. J Pure Appl Microbiol, 2012; 6(3):1303-1308.

Chang CC, Yang MH, Wen HM, Chern JC. Estimation of total flavonoid content in propolis by two complementary colorimetric methods. J Food Drug Anal, 2002; 10(3):178-182.

Cui XS, Guo YH. Analysis of mineral elements in different organs of Chrysanthemum indicum L. based on ICP-AES. Guang Pu Xue Yu Guang Pu Fen Xi, 2012; 32(10):2828-2830.

DuBoise M, Gilles K, Hamilton J, Rebers PA, Smith F. Colorimetric method for determination of sugars and related substances. Anal Chem, 1956; 28(3):350-356.

Dukes J. 2013. Phytochemical and Ethnobotanical Databases. [ONLINE] Available at: http://www.ars-gov/cgi-bin/duke/. [Accessed 12 April 2016].

Ghani A, Ali Z, Islam T, Sanaullah S, Saeed S. Report: nutrient evaluation and elemental analysis of four selected medicinal plants of soon valley Khushab, Punjab, Pakistan. Pak J Pharm Sci, 2014; 27(3):597-600.

Harborne JB. 1998. Phytochemical methods: A guide to modern techniques of plant analysis. Chapman and Hall, London.

Hawaze S, Deti H, Suleman S. In vitro antimicrobial activity and phytochemical screening of Clematis species indigenous to Ethiopia. Indian J Pharm Sci, 2012; 74(1):29-35.

He B, Rhodes BS, Miller MR, Munson AE, Germolec DR, Walker VR, Korach KS, Meade BJ. Octamethylcyclotetrasiloxane exhibits estrogenic activity in mice via ER $\alpha$. Toxicol Appl Pharmacol, 2003; 192(3):254-261.

Hemalatha R, Nivetha P, Mohanapriya C, Sharmila G, Muthukumaran C, Gopinath M. Phytochemical composition, GC-MS analysis, in vitro antioxidant and antibacterial potential of clove flower bud (Eugenia caryophyllus) methanol extract. J Food Sci Technol, 2016; 53(2):1189-1198.

Jayaraman J. 1981. Laboratory Manual in Biochemistry. Wiley Eastern Limited, New Delhi.

Koleckar V, Kubikova K, Rehakova Z, Kuca K, Jun D, Jahodar L, Opletal L. Condensed and hydrolysable tannins as antioxidants influencing the health. Min Rev Med Chem, 2008; 8(5):436-447.

Komuraiah B, Srinivas C, Niranjana Kumar A, Satya Srinivas KVN, Venu Ch, Kotesh Kumar J, Sastry KP, Paramjit G. Isolation of phytochemicals from anticancer active extracts of Syzygium alternifolium Walp. leaf. Pharmacogn J, 2014; 6(4):83-85. 
Kopka J. Gas chromatography-mass spectrometry. Biotechnol Agric For, 2006; 57:3-20.

Krishna SRA, Hafza S, Poorna Chandrika G, Lekhya Priya C, Bhaskara Rao KV. Pharmacological properties, phytochemical and GCMS analysis of Bauhinia acuminata Linn. J Chem Pharm Res, 2015; 7(4):372-380.

Kumar NV, Reddy JS, Gopikrishna G, Solomon KA. GC-MS determination of bioactive constituents of Cycas beddomei cones. Int J Pharm Bio Sci, 2012; 3(3):344-350.

Liu L, Chen YY, Qin XJ, Wang B, Jin Q, Liu YP, Luo XD. Antibacterial monoterpenoid indole alkaloids from Alstonia scholaris cultivated in temperate zone. Fitoterapia, 2015; 105:160-164.

Lowry OH, Rosebrough NJ, Farr AL, Randall RJ. Protein measurement with the folin phenol reagent. J Biol Chem, 1951; 193:265275

Maiti A, Cuendet M, Kondratyuk T. Synthesis and cancer chemopreventive activity of zapotin, a natural product from Casimiroa edulis. J Med Chem, 2007; 50(2):350-355.

Makkar HPS, Blummel M, Borowy NK, Becker K. Gravimetric determination of tannins and their correlations with chemical and protein precipitation methods. Journal of Science and Food Agriculture, 1993; 61(2):161-165.

Marschner H, Kirkby EA, Cakmak I. Effect of mineral nutritional status on shoot-root partitioning of photoassimilates and cycling of mineral nutrients. J Exp Bot, 1996; 47:1255-1263.

McCready RM, Guggoiz J, Silviera V, Owens HS. Determination of starch and amylase in vegetables. Anal Chem, 1950; 22(9):1156-1158.

Mostafa AA, Al-Rahmah AN, Abdel-Megeed A. Evaluation of some plant extracts for their antifungal and antiaflatoxigenic activities. J Med Plants Res, 2011; 5(17):4231-4238.

Nakamura Y, Watanabe S, Miyake N, Kohno H, Osawa T. Dihydrochalcones: evaluation as novel radical scavenging antioxidants. J Agric Food Chem, 2003; 51(11):3309-3312.

Ndhlala AR, Muchuweti M, Mupure C, Chitindingu K, Murenje T, Kasiyamhuru A, Benhura MA Phenolic content and profiles of selected wild fruits of Zimbabwe: Ximenia caffra, Artobotrys brachypetalus and Syzygium cordatum. Int J Food Sci Technol, 2008; 43:1333-1337.

Omran SM, Esmailzadeh S. Comparison of anti-candida activity of thyme, pennyroyal, and lemon essential oils versus antifungal drugs against Candida species. Jundishapur J Microbiol, 2009; 2(2):53-60.

Pandey M, Abidi AB, Singh S, Singh RP. Nutritional evaluation of leafy vegetable paratha. J Hum Ecol, 2006; 19(2):155-156.

Reddy NVLS, Kusuma Priyanka AY, Raghavendra NM. Isolation and characterization of triterpenoids from bark of Syzygium alternifolium (Wight) Walp. Annals of Phytomedicine, 2012; 1(2):45-51.

Saha D, Ved D, Ravikumar K, Haridasan K. Syzygium alternifolium. The IUCN Red List of Threatened Species 2015: e.T50130683A50131435.

Sasidharan S, Chen Y, Saravanan D, Sundram KM, Yoga Latha L. Extraction, isolation and characterization of bioactive compounds from plants extracts. Afr J Tradit Complement Altern Med, 2011; 8(1):110.

Savithramma N, Linga Rao M, Yugandhar P, Hari Babu R. Ethnobotanical study of Penchalakona forest area of Nellore district, Andhra Pradesh, India. Int J Phytomed, 2012; 4(3):333-339.

Savithramma N, Yugandhar P, Hari Babu R, Siva Prasad K. Validation of indigenous knowledge of yanadi tribe and local villagers of Veyilingalakona-a sacred grove of Andhra Pradesh, India. J Pharm Sci Res, 2014; 6(11):382-388.

Savithramma N, Yugandhar P, Linga Rao M. Ethnobotanical studies on japali hanuman theertham-a sacred grove of Tirumala hills, Andhra Pradesh, India. J Pharm Sci Res, 2014; 6(2):83-88.

Savitramma N, Sulochana Ch. Endemic medicinal plants from Tirumala hills, Andhra Pradesh, India. Fitoterapia, 1997; 69(3):253-254.
Senila M, Drolc A, Pintar A, Senila L, Levei E. Validation and measurement uncertainty evaluation of the ICP-OES method for the multielemental determination of essential and nonessential elements from medicinal plants and their aqueous extracts. J Anal Sci Technol, 2014; 5(37):1-9.

Shirin K, Imad S, Shafiq S, Fatima K. Determination of major and trace elements in the indigenous medicinal plant Withania somnifera and their possible correlation with therapeutic activity. J Saudi Chem Soc, 2010; 14(1):97-100

Sidney MT, Siyabonga SJ, Kotze BA. Evaluation of the antibacterial activity of Syzygium cordatum fruit pulp and seed extracts against bacterial strains implicated in gastrointestinal tract infections. Afr J Biotechnol, 2015; 14(16):1387-1392.

Sihag S, Pareek S, Varshney S. Structural and antimicrobial investigations of some new silicon (IV) complexes with azomethines of amino acids. Chem Sci Rev Lett, 2014; 3(11):498-505.

Soares MO, Alves RC, Pires PC, Oliveira MB, Vinha AF. Angolan Cymbopogon citratus used for therapeutic benefits: nutritional composition and influence of solvents in phytochemicals content and antioxidant activity of leaf extracts. Food Chem Toxicol, 2013; 60:413418.

Szentmihalyi K, Hethelyi E, Virag V, Then M. Mineral elements in muscat sage plant (Salvia sclarea L.) and essential oil. Acta Biologica Szegediensis, 2009; 53(1):35-38.

Tapiero H, Tew KD, Ba GN, Mathe G. Biomed, Polyphenols: do they play a role in the prevention of human pathologies? Pharmacother, 2002; 56 (4):200-207.

The Wealth of India. 1976. Raw materials. In: Publication and information directorate (ed). Council of Scientific and Industrial Research, New Delhi.

Trease GE, Evans WC. Pharmacognosy. 2002. WB Saunders, Elsevier Science Limited, Philadelphia.

Turan M, Kordali S, Zengin H, Dursun A, Sezen Y. Macro and micro mineral content of some wild edible leaves consumed in Eastern Anatolia. Acta Agric Scand Sect B, 2003; 53(3):129-137.

Wang R, Moody RP, Koniecki D, Zhu J. Low molecular weight cyclic volatile methylsiloxanes in cosmetic products sold in Canada: implication for dermal exposure. Environ Int, 2009; 35(6):900-904.

Xie JH, Dong CJ, Nie SP, Li F, Wang ZJ, Shen MY, Xie MY. Extraction, chemical composition and antioxidant activity of flavonoids from Cyclocarya paliurus (Batal.) Iljinskaja leaves. Food Chem, 2015; 186 (1):97-105.

Yamashita CI, Saiki M, Vasconcellos MBA, Sertie JA. Characterization of trace elements in Casearia medicinal plant by neutron activation analysis. Appl Radiat Isot, 2005; 63(5-6):841-846.

Yugandhar P, Haribabu R, Savithramma N. Synthesis, characterization and antimicrobial properties of green-synthesised silver nanoparticles from stem bark extract of Syzygium alternifolium (Wt.) Walp. 3 Biotech, 2015; 5:1031-1039.

Zhang P, Shao L, Shi Z, Zhang Y, Du J, Cheng K, Yu P. Pregnane alkaloids from Sarcococca ruscifolia and their cytotoxic activity. Phytochem Lett, 2015; 14:31-34

\section{How to cite this article:}

Yugandhar P, Savithramma N. Spectroscopic and chromatographic exploration of different phytochemical and mineral contents from Syzygium alternifolim (Wt.) Walp. an endemic, endangered medicinal tree taxon. J App Pharm Sci, 2017; 7 (01): 073-085. 